EdWards, D. C. \& Seamer, P. A. (1960). J. gen. Microbiol. 22, 705-712

\title{
The Uptake of Iron by Corynebacterium diphtheriae Growing in Submerged Culture
}

\author{
By D. C. EDWARDS ANd P. A. SEAMER \\ Wellcome Research Laboratories (Biological Division), Langley Court, \\ Beckenham, Kent
}

SUMMARY: The uptake of iron by Corynebacterium diphtheriae growing in complex medium was found to be rapid and quantitative, even when the iron concentration of the medium was high enough to abolish toxin production completely. The presence of this inhibitory concentration of iron $(3 \mu \mathrm{g} . / \mathrm{ml}$.) did not alter the duration of logarithmic growth nor did it affect the shape of the growth curve in any other way. The ferrous and ferric forms of iron were taken up equally well by the organism and appeared, weight for weight, to give the same final toxin titres. Ferrous iron, however, appeared to begin to exert its effect on toxin synthesis much earlier in the growth period than did ferric iron. It is suggested that perhaps only ferrous iron is inhibitory and that ferric iron requires to be converted to the ferrous form before exerting its effect.

Although the effect of iron in inhibiting toxin production by Corynebacterium diphtheriae has been known for many years (Locke \& Main, 1931; Pope, 1932; Pappenheimer \& Johnson, 1936), few studies have been made of the actual uptake of iron by the organism, and in fewer still does it appear that the course of the uptake of iron has been followed throughout the active growth curve. In the present work toxin production, growth and iron uptake were followed during the course of growth at iron concentrations intermediate between those necessary for the complete abolition of toxin production and those used for maximum production of toxin. The effects of ferrous and ferric iron were compared and also the effects of ferric citrate and ferric chloride as sources of iron for the organism.

\section{METHODS}

Methods of cultivation. The organism and medium were as described in the previous paper and submerged growth was carried out in 20 l. tanks containing 11 1. medium and $15 \mathrm{ml} .25 \%(\mathrm{w} / \mathrm{v})$ antifoam $A$ in butyl acetate (Edwards, 1960). The temperature was maintained at $35^{\circ}$ and air $(500 \mathrm{ml} . / \mathrm{min}$.) was passed over the surface of the stirred culture.

Bacterial dry weights and viable counts. These were done as described in the previous paper (Edwards, 1960).

Iron estimations. The wet ash method described by Seamer (1959) was used. The cultures were centrifuged and the iron content of both supernatant fluid and of the bacteria estimated. The bacteria were not washed as the difference made by washing was found to be negligible. The results for bacterial iron are expressed either as $\mu \mathrm{g}$. bacterial $\mathrm{Fe} / \mathrm{ml}$. culture or as $\mu \mathrm{g}$. $\mathrm{Fe} / \mathrm{mg}$. dry bacteria. 
Gas analyses. The effluent gases from the tanks were collected over acidified water and analysed for $\mathrm{CO}_{2}$ and $\mathrm{O}_{2}$ by absorption first with $\mathrm{KOH}$ and then with alkaline pyrogallol in the usual manner.

Toxin. This was estimated by the flocculation method (Ramon, 1922; Glenny \& Okell, 1924). Results are expressed as Lf units/ml.

\section{RESULTS}

Ferrous iron. A preliminary experiment (Table 1, SC 1427), on the uptake of iron by Corynebacterium diphtheriae growing in submerged culture and on the disappearance of iron from the medium, showed that the uptake of iron by the organisms was virtually quantitative by the 18th hr. of growth. The amount of iron left in the medium was so small that it was at the limit of sensitivity of the method of determination. The iron was firmly bound to the organisms and was not removed by washing with $0.9 \%$ saline. When $0.001 \mathrm{~N}$ $\mathrm{HCl}$ and $0.01 \mathrm{~N}-\mathrm{HCl}$ were used for the washing, organisms containing $0.09 \mu \mathrm{g}$. $\mathrm{Fe} / \mathrm{ml}$. culture gave $0.08 \mu \mathrm{g}$. Fe/ml. Organisms containing $0.10 \mu \mathrm{g}$. $\mathrm{Fe} / \mathrm{ml}$. culture were washed with $0 \cdot 1 \mathrm{~N}-\mathrm{HCl}$ and $\mathrm{N}-\mathrm{HCl}$ and gave $0.09 \mu \mathrm{g} . \mathrm{Fe} / \mathrm{ml}$. and $0.07 \mu \mathrm{g} . \mathrm{Fe} / \mathrm{ml}$. respectively. Thus it appears that only $\mathrm{N}-\mathrm{HCl}$ removed more iron than could be accounted for by experimental error.

In view of the rapid uptake of iron from the medium found in the preliminary experiment it was decided to investigate the effect on the organisms of adding increasing amounts of iron to the tank cultures. Six experiments were performed in which iron concentrations of $0 \cdot 18,0.35,0.55,1.34,1.85$ and $3 \cdot 10 \mu \mathrm{g} . / \mathrm{ml}$., respectively, were used. Lf $/ \mathrm{ml}$. values of $270,210,176,54,8$ and 0 , respectively, were obtained after growth for $48 \mathrm{hr}$. Although in the present study the toxin titres were in a clear inverse proportion to the amount of iron added to the cultures, it must be emphasized that any curve constructed from these values, however smooth it might be, could not be used to predict accurately the toxin titres that would be produced in future experiments. This is especially true when the lower concentrations of added iron are considered, for here other as yet unknown factors play a major part in determining the final toxin titres.

Table 1 shows the iron uptakes by organisms as growth proceeded at the different iron concentrations and the disappearance of iron from the medium. In every case iron was rapidly taken up by the organisms. At the lowest concentration used, nearly $90 \%$ of the iron had been removed from the medium by the 18th hr. of growth, at which time the bacterial dry wt. had reached only approximately one-third of its final value. At higher concentrations of iron, the uptake was not complete until later in the growth period; but even when $3 \mu \mathrm{g}$. Fe/ml. were added the iron had virtually all been taken up by the 30th hr. of growth.

Figure 1 shows the iron concentration in organisms as $\mu \mathrm{g}$. Fe/mg. dry wt. organism; it shows quite clearly how the iron concentration of the organisms changed as growth proceeded. The point at which flocculable toxin was first detected is arrowed and the amount of the toxin (as $\mathrm{Lf} / \mathrm{ml}$.) at this point is 
Table 1. The uptake of iron by Corynebacterium diphtheriae growing in submerged culture

Results are expressed as $\mu \mathrm{g}$. bacterial iron $/ \mathrm{ml}$. culture and as $\mu \mathrm{g}$. iron $/ \mathrm{ml}$. supernatant fluid. Time (hr.)

\begin{tabular}{|c|c|c|c|c|c|c|c|c|c|}
\hline Expt. & & 0 & 12 & 18 & $\begin{array}{c}24 \\
\text { on con }\end{array}$ & $\begin{array}{l}30 \\
\text { trati }\end{array}$ & 36 & 42 & 48 \\
\hline SC 1427 & $\begin{array}{l}\text { Bacteria } \\
\text { Supernatant }\end{array}$ & $\overline{0.13}$ & $\overline{0.03}$ & $\begin{array}{l}0 \cdot 13 \\
0 \cdot 00\end{array}$ & $\begin{array}{l}0 \cdot 12 \\
0 \cdot 00\end{array}$ & $\begin{array}{l}0 \cdot 12 \\
0 \cdot 00\end{array}$ & $\begin{array}{l}0 \cdot 13 \\
0 \cdot 00\end{array}$ & $\begin{array}{l}0 \cdot 13 \\
0 \cdot 00\end{array}$ & $\begin{array}{l}0 \cdot 13 \\
0 \cdot 00\end{array}$ \\
\hline SC 1499 & $\begin{array}{l}\text { Bacteria } \\
\text { Supernatant }\end{array}$ & $\overline{0 \cdot 18}$ & $\begin{array}{l}0.10 \\
0.07\end{array}$ & $\begin{array}{l}0 \cdot 14 \\
0 \cdot 03\end{array}$ & $\begin{array}{l}0 \cdot 15 \\
0.03\end{array}$ & $\begin{array}{l}0 \cdot 16 \\
0 \cdot 02\end{array}$ & $\begin{array}{l}0 \cdot 16 \\
0 \cdot 02\end{array}$ & $\begin{array}{l}0 \cdot 16 \\
0 \cdot 02\end{array}$ & $\begin{array}{l}0 \cdot 16 \\
0 \cdot 02\end{array}$ \\
\hline SC 1491 & $\begin{array}{l}\text { Bacteria } \\
\text { Supernatant }\end{array}$ & $\overline{0.35}$ & $\begin{array}{l}0 \cdot 20 \\
0 \cdot 15\end{array}$ & $\begin{array}{l}0.27 \\
0 \cdot 08\end{array}$ & $\begin{array}{l}0.32 \\
0.03\end{array}$ & $\begin{array}{l}0 \cdot 34 \\
0 \cdot 01\end{array}$ & $\begin{array}{l}0.34 \\
0 \cdot 01\end{array}$ & - & $\begin{array}{l}0.35 \\
0.01\end{array}$ \\
\hline SC 1443 & $\begin{array}{l}\text { Bacteria } \\
\text { Supernatant }\end{array}$ & $\overline{0.55}$ & $\begin{array}{l}0 \cdot 29 \\
0 \cdot 25\end{array}$ & $\begin{array}{l}0 \cdot 42 \\
0 \cdot 11\end{array}$ & $\begin{array}{l}0.51 \\
0.02\end{array}$ & $\begin{array}{l}0.54 \\
0.02\end{array}$ & $\begin{array}{l}0.54 \\
0.02\end{array}$ & $\begin{array}{l}0.52 \\
0.02\end{array}$ & $\begin{array}{l}0.54 \\
0.02\end{array}$ \\
\hline SC 1451 & $\begin{array}{l}\text { Bacteria } \\
\text { Supernatant }\end{array}$ & $\overline{1 \cdot 34}$ & $\begin{array}{l}0.40 \\
0.92\end{array}$ & $\begin{array}{l}0.98 \\
0.40\end{array}$ & $\begin{array}{l}1 \cdot 10 \\
0 \cdot 05\end{array}$ & $\begin{array}{l}1 \cdot 30 \\
0 \cdot 02\end{array}$ & $\begin{array}{l}1 \cdot 30 \\
0 \cdot 02\end{array}$ & $\begin{array}{l}1 \cdot 32 \\
0 \cdot 03\end{array}$ & $\begin{array}{l}1 \cdot 30 \\
0.02\end{array}$ \\
\hline SC 1459 & $\begin{array}{l}\text { Bacteria } \\
\text { Supernatant }\end{array}$ & $\overline{1.85}$ & $\begin{array}{l}0 \cdot 94 \\
0 \cdot 86\end{array}$ & - & $\begin{array}{l}1 \cdot 64 \\
0 \cdot 23\end{array}$ & $\begin{array}{l}1.87 \\
0.03\end{array}$ & $\begin{array}{l}1.87 \\
0.03\end{array}$ & $\begin{array}{l}1.85 \\
0 \cdot 02\end{array}$ & $\begin{array}{l}1.85 \\
0.03\end{array}$ \\
\hline SC 1467 & $\begin{array}{l}\text { Bacteria } \\
\text { Supernatant }\end{array}$ & $\overline{3 \cdot 10}$ & $\begin{array}{l}1 \cdot 15 \\
1 \cdot 90\end{array}$ & $\begin{array}{l}1 \cdot 90 \\
1 \cdot 30\end{array}$ & $\stackrel{2 \cdot 75}{-}$ & $\begin{array}{l}3 \cdot 10 \\
0 \cdot 02\end{array}$ & $\begin{array}{l}3 \cdot 10 \\
0 \cdot 02\end{array}$ & $\begin{array}{l}3 \cdot 20 \\
0 \cdot 03\end{array}$ & $\begin{array}{l}3 \cdot 10 \\
0 \cdot 03\end{array}$ \\
\hline
\end{tabular}

indicated in each case. In Fig. 1 most of the iron values start at $12 \mathrm{hr}$. as the dry weight of organism and the iron content of the $6 \mathrm{hr}$. sample were too low to permit accurate determination; in one case, where the result for $12 \mathrm{hr}$. was missing, the $6 \mathrm{hr}$. value has been shown. The point at which flocculation first became detectable is seen to shift steadily along the time axis as the iron concentration in the medium was increased until eventually no toxin was found. It would appear from the values shown that between $0 \cdot 14$ and $0 \cdot 16 \mu \mathrm{g}$. $\mathrm{Fe} / \mathrm{mg}$. bacterial dry wt. was required to inhibit toxin production completely. At the lower concentrations of iron it is doubtful whether values of this order would ever be reached, but it seems none the less likely that the organisms would, in the early stage of growth, contain sufficient iron to cause at least a partial inhibition of toxin production.

Since it seemed that the most likely role that iron might play was in affecting oxygen uptake the effluent gases from the tanks were analysed to see whether any changes could be detected as between cultures at different Fe concentrations. The results are shown in Table 2. No significant differences were found as between the $\mathrm{O}_{2}$ content of the effluent gases from tanks containing three widely different iron concentrations and producing different yields of toxin. In the first case the volume of air passing was $500 \mathrm{ml}$./per min. and so the figures can also be taken to represent the percentage available oxygen absorbed. It is obvious that the organism had a high rate of oxygen consumption; it removed upwards of $70 \%$ of that being passed into the tank. This failure to detect differences in the oxygen uptake between organisms containing such widely different iron concentrations is surprising in view of the fact that in our experience it is usually necessary to increase the air supply 


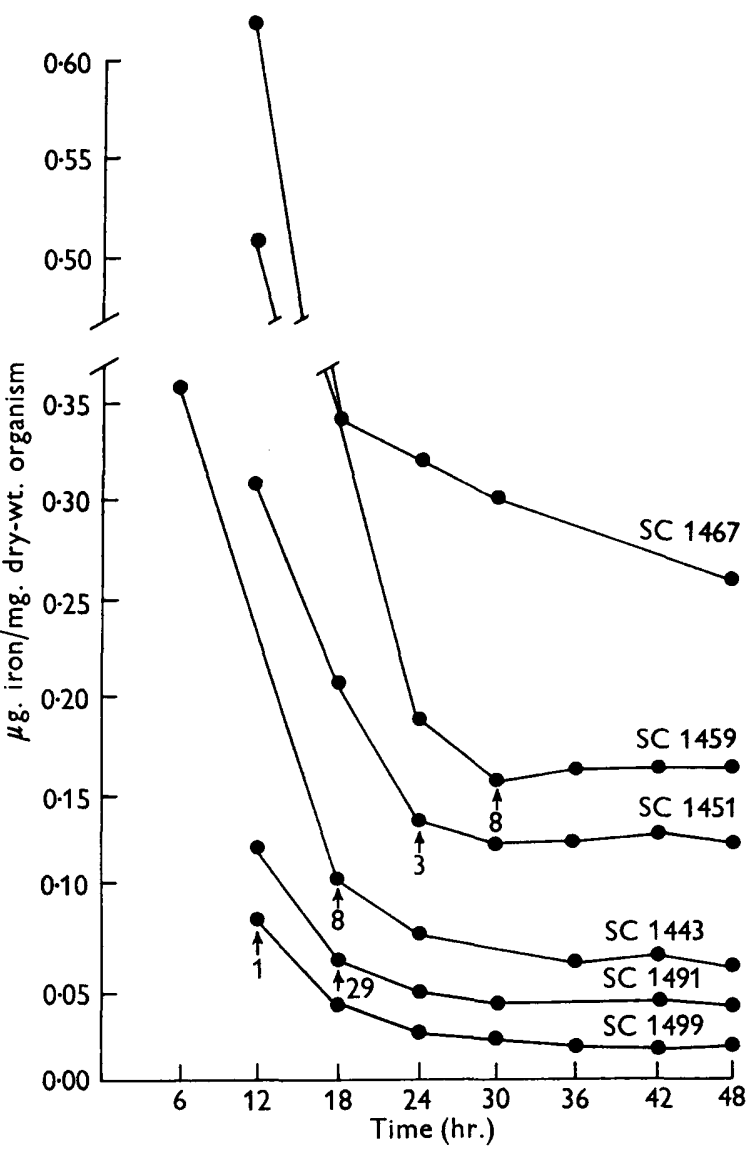

Fig. 1. The iron content of bacteria growing in different iron concentrations. The point at which toxin was first detected is arrowed and the titre $(\mathrm{Lf} / \mathrm{ml}$.) found is indicated.

Table 2. Oxygen uptake of Corynebacterium diphtheriae growing in submerged culture on media with different iron concentrations

\begin{tabular}{|c|c|c|c|c|c|c|c|c|c|c|c|c|}
\hline \multirow[b]{2}{*}{ Expt. no. } & \multirow{2}{*}{$\begin{array}{c}\text { Fe concn. } \\
\text { of } \\
\text { medium } \\
(\mu \mathrm{g} . / \mathrm{ml} .)\end{array}$} & \multirow{2}{*}{$\begin{array}{c}\text { Final } \\
\text { toxin } \\
\text { titre } \\
\text { (Lf/ml.) }\end{array}$} & \multirow{2}{*}{$\begin{array}{c}\text { Volume } \\
\text { of air } \\
\text { passing } \\
\text { (ml./min.) }\end{array}$} & \multicolumn{9}{|c|}{ Time (hr.) } \\
\hline & & & & 2 & 6 & 12 & 18 & 24 & 30 & $\mathbf{3 6}$ & 42 & 48 \\
\hline & & & & \multicolumn{9}{|c|}{ Oxygen uptake (ml./min.) } \\
\hline SC 1499 & $\mathbf{0} \cdot 18$ & 270 & 500 & $\longrightarrow$ & - & - & 63 & 62 & 72 & $\mathbf{5 2}$ & $\mathbf{2 9}$ & 11 \\
\hline SC 1451 & 1.34 & 54 & 600 & $\mathbf{0}$ & 7 & 32 & 64 & 68 & 79 & 70 & 24 & 7 \\
\hline SC 1467 & $3 \cdot 10$ & 0 & 600 & $\mathbf{0}$ & 6 & 51 & 69 & 74 & 77 & - & 13 & 3 \\
\hline
\end{tabular}

when the iron concentration is high in order to stop the $\mathrm{pH}$ value from dropping too low.

Since the oxygen uptake did not increase much after $18 \mathrm{hr}$. of growth it seems possible that the oxygen supply was limiting the growth rate. Pappenheimer (1955) suggested that the limited iron supply might be responsible for 
the growth curve deviating from the exponential. The present results do indeed show that at the lowest iron concentrations investigated the iron uptake was complete after about $18 \mathrm{hr}$. which corresponded roughly to the end of logarithmic growth. Figure 2 shows the viable counts of cultures containing 0.18 and $3 \cdot 1 \mu \mathrm{g}$. Fe/ml. and which produced 270 and $0 \mathrm{Lf} / \mathrm{ml}$. respectively. Clearly it is not possible to distinguish between the two curves, and the presence of sufficient iron to suppress toxin production completely had no influence on the time of the deviation from logarithic growth. Since it has been shown already (Table 1) that iron uptake by organisms where $3 \cdot 1 \mu \mathrm{g}$. $\mathrm{Fe} / \mathrm{ml}$. were present was incomplete until the 30th hr. of growth, it is clear that iron was not the factor which limited the duration of logarithmic growth.

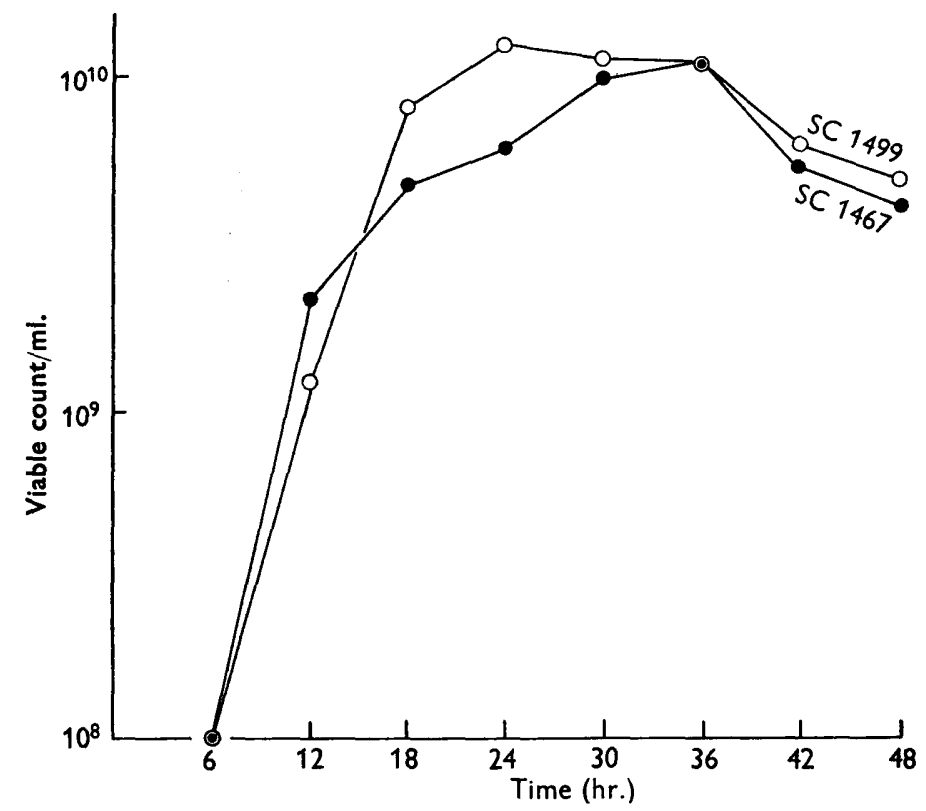

Fig. 2. Viable counts of cultures with and without added iron. $\bigcirc-O$, medium contained $1.8 \mu \mathrm{g}$. iron $/ \mathrm{ml}$.; $\longrightarrow$, medium contained $3 \cdot 1 \mu \mathrm{g}$. iron $/ \mathrm{ml}$.

Ferric iron. Following the experiments with ferrous iron the uptake of ferric iron by cultures of Corynebacterium diphtheriae was investigated. For this purpose ferric chloride and ferric citrate were used; the iron uptakes are shown in Table 3. As with ferrous iron the uptake was rapid and almost quantitative with both salts; each provided a readily available source of iron for the organism. The iron uptake appeared to be equally rapid whether ferric or ferrous iron was added, but the two types of iron produced different rates of toxin synthesis. Table 4 shows the progress of toxin production when the organism was grown at two concentrations of ferric and ferrous iron. Inhibition of toxin production occurred to much the same extent by $48 \mathrm{hr}$. whichever form of iron was added (when comparable iron contents are compared), but 
ferrous iron greatly delayed the appearance of toxin whereas ferric iron did not. Indeed the cultures containing ferric iron started to produce toxin as though no inhibitory concentration of iron had been added. Thus ferric iron appears to exert its effect on toxin production by slowing the rate of synthesis in the later stages of growth. Since ferric iron in these cultures was rapidly taken up by the organism, this failure to inhibit toxin production immediately suggests that perhaps only ferrous iron is inhibitory and that a conversion of ferric to ferrous iron must be accomplished within the cell before inhibition can occur. The rate of conversion would then determine the time at which inhibition became apparent.

Table 3. The uptake of ferric iron by Corynebacterium diphtheriae growing in submerged culture

Results are expressed as $\mu \mathrm{g}$. bacterial iron $/ \mathrm{ml}$. culture and as $\mu \mathrm{g}$. iron $/ \mathrm{ml}$. supernatant fluid. In Expt. SC 1575 the iron was added as ferric citrate, in SC 1567 as ferric chloride.

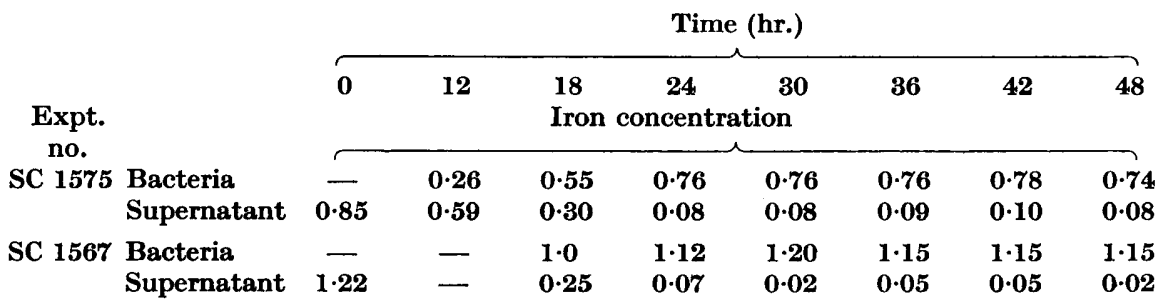

Table 4. Toxin production by Corynebacterium diphtheriae growing on media containing different concentrations of ferric or ferrous iron

\begin{tabular}{|c|c|c|c|c|c|c|c|c|c|c|}
\hline \multirow{4}{*}{ Expt. no. } & \multirow{2}{*}{\multicolumn{2}{|c|}{ Iron }} & \multicolumn{8}{|c|}{ Time (hr.) } \\
\hline & & & \multirow{2}{*}{6} & \multirow{2}{*}{12} & \multirow{2}{*}{$\begin{array}{c}18 \\
\text { oxin }\end{array}$} & \multirow{2}{*}{$\begin{array}{l}\mathbf{2 4} \\
\text { pro }\end{array}$} & \multirow{2}{*}{$\begin{array}{c}\text { 30 } \\
\text { luct }\end{array}$} & \multirow{2}{*}{$\begin{array}{c}36 \\
\text { n (L) }\end{array}$} & \multirow{2}{*}{$\begin{array}{r}42 \\
/(\mathrm{ml} .)\end{array}$} & \multirow[t]{2}{*}{48} \\
\hline & & Concn. & & & & & & & & \\
\hline & 1уре & $(\mu \mathrm{g} / \mathrm{M}$ & & & & & & & & \\
\hline SC 1451 & Ferrous & $1 \cdot 34$ & 0 & $\mathbf{0}$ & $\mathbf{0}$ & 3 & 7 & 27 & 46 & 54 \\
\hline SC 1567 & Ferric & $1 \cdot 22$ & 0 & 1 & 4 & 12 & 23 & 35 & 55 & 68 \\
\hline SC 1443 & Ferrous & 0.55 & 0 & 0 & 8 & $\mathbf{5 5}$ & 98 & 132 & 164 & 176 \\
\hline SC 1575 & Ferric & $0 \cdot 85$ & $\mathbf{0}$ & 4 & 12 & 31 & 58 & 74 & 92 & 108 \\
\hline
\end{tabular}

\section{DISCUSSION}

The decrease in toxin titre from 270 to $0 \mathrm{Lf} / \mathrm{ml}$. as the iron concentration of the medium was increased from $0 \cdot 18$ to $3 \cdot 1 \mu \mathrm{g} / \mathrm{ml}$. shows that, although the iron concentration is undoubtedly important, a complex medium such as was used in the present work is by no means as sensitive to the presence of iron as is a simpler chemically defined medium in which it seems agreed (Pappenheimer, 1947; Clarke, 1958) that c. $0 \cdot 6 \mu \mathrm{g}$. Fe/ml. is sufficient to decrease toxin production virtually to zero. This difference in sensitivity is not due to iron remaining in the complex medium in some form unavailable to the organism, for the quantitative transfer of iron to the organisms was clearly shown in every case studied. It seems more likely therefore that the difference may lie in different growth-promoting qualities of the two types of media. 
The rapid and quantitative uptake of iron reported here is not in agreement with the results quoted by Clarke (1958) on the uptake of iron from a defined medium. In his experiments iron uptake continued for $113 \mathrm{hr}$. and even then was less than $70 \%$ complete. These differences are presumably due to the fact that while Clarke used static cultures in which the iron could only reach the surface film of organism by diffusion through the medium, the present method of submerged culture in which the organisms are uniformly dispersed is not subject to such an effect. However Pappenheimer (1947), using surface culture, found that iron added to his medium was 'recovered quantitatively from the bacterial cells'; no explanation of the discrepancy in the results of these two workers is obvious.

It has been stated in the Results section that the theory (Pappenheimer, 1955) that iron limited the period of logarithmic growth does not hold under the present conditions since the presence of sufficient iron to abolish toxin synthesis did not materially affect the shape of the growth curve. It does appear, however, that iron has a marked effect on the time at which toxin synthesis begins and that as more iron is added synthesis of toxin becomes more and more delayed. Also, the presence of relatively high concentrations of iron per unit weight of organism in the early stages of growth suggests that the rate of toxin production must be limited. This appears to be in agreement with the views of Raynaud, Alouf \& Mangalo (1959) who used defined media and submerged culture methods; they concluded that toxin was secreted into the medium probably from the beginning of growth but that toxin formation was highest during the long slow period of growth following the exponential phase. In the present work it is not claimed that there was no toxin at all formed in the early stages of growth when the iron content of the medium was low. It is clear that any toxin formed was negligible in amount and, further, that as the iron content of the medium was increased it became less likely that any significant amount of toxin would be formed until the iron content/mg. dry wt. organism had fallen to $c .0 \cdot 14-0 \cdot 16 \mu \mathrm{g}$. Fe. Thus iron does not act by slowing toxin production over the whole of the growth curve but rather by delaying the start of its production. Once a start has been made toxin production is usually rapid though the final titres found may be quite small, suggesting that perhaps only a small percentage of organisms have passed through a toxigenic phase.

We wish to express our thanks to Dr C. G. Pope for advice, and to the staff of the Toxin Laboratory for inoculating and sampling the tanks.

\section{REFERENCES}

Clarke, G. D. (1958). The effect of ferrous irons on the formation of toxin and porphyrin by a strain of Corynebacterium diphtheriae. J. gen. Microbiol. 18, 698.

EDwards, D. C. (1960). The growth and toxin production of Corynebacterium diphtheriae in submerged culture. J. gen. Microbiol. 22, 699.

GlenNy, A. T. \& OkeLL, C. C. (1924). The titration of diphtheria toxin and antitoxin by flocculation methods. J. Path. Bact. 27, 187. 
Locke, A. \& MAIN, E. R. (1931). The relation of copper and iron to production of toxin and enzyme action. J. infect. Dis. 48, 419.

Pappenheimer, Jun., A. M. (1947). Diphtheria toxin. III. A reinvestigation of the effect of iron on toxin and porphyrin production. J. biol. Chem. 167, 251.

Pappenheimer, Jun., A. M. (1955). The pathogenesis of diphtheria. Symp. Soc. gen. Microbiol. 5, 40.

Pappenheimer, Jun., A. M. \& Johnson, S. J. (1936). Studies in diphtheria toxin production. I. The effect of iron and copper. Brit. J. exp. Path. 17, 335.

Pope, C. G. (1932). The production of toxin by C. diphtheriae. II. Effects produced by addition of iron and copper to the medium. Brit. J. exp. Path. 13, 218.

Ramon, G. (1922). Floculation dans un mélange neutre de toxin-antitoxine diphtériques. C.R. Soc. Biol., Paris, 86, 661.

Raynaud, M., Alouf, J. \& Mangalo, R. (1959). Croissance et toxinogénèse diphtériques en culture agitée, sur milieu synthétique. Ann. Inst. Pasteur, 96, 276.

Seamer, P. A. (1959). Estimation of microgram quantities of iron in culture medium using bathophenanthroline. Nature, Lond. 184, 636.

(Received 13 November 1959) 